\title{
インテグラル立体映像方式における要素画像群の歪曲の影響
}

\section{Effects of Elemental Images Distortion in Integral Three-dimensional Imaging}

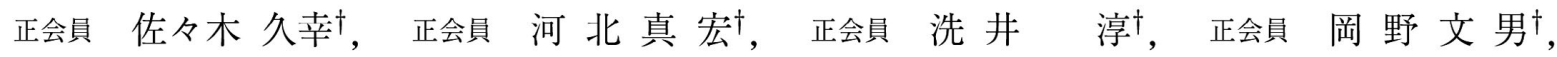

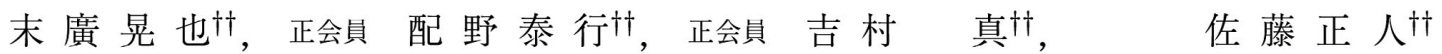

Hisayuki Sasaki ${ }^{\dagger}$, Masahiro Kawakita ${ }^{\dagger}$, Jun Arai ${ }^{\dagger}$, Fumio Okano $^{\dagger}$, Koya Suehiro $^{\dagger \dagger}$, Yasuyuki Haino ${ }^{\dagger \dagger}$, Makoto Yoshimura ${ }^{\dagger \dagger}$ and Masahito Sato ${ }^{\dagger \dagger}$

\begin{abstract}
We have been conducting research with the objective of achieving three-dimensional (3D) television using integral photography. Extremely high-resolution (EHR) elemental images are necessary to enhance integral 3D image quality. Presently, projection display systems are practical for displaying EHR images and have some advantages for 3D imaging. However, any geometric distortion of the projection lens will cause a positional error between the elemental images and elemental lenses. This positional error subsequently results in a distortion of the reconstructed image and a smaller viewing area. We theoretically and experimentally analyzed the effects of distorted elemental images on a reconstructed image. As a result, a slight distortion of the projection lens, which is proportional to the square of the image height, caused a positional error of the reconstructed 3D image. The depth-direction error of the reconstructed image was larger than that of the lateral direction. Furthermore, the viewing area decreased due to the distortion of the elemental images. From experimental results using a projection-type integral system, we found that image processing for distortion compensation is effective in eliminating distortion and improving the viewing area of the reconstructed 3D image.
\end{abstract}

キーワード：立体映像，インテグラル式, 要素画像, 投射型デイスプレイ, 幾何学歪み, 視域

\section{1. まえがき}

近年，高臨場感映像技術に対する期待が高まっており，研 究開発や実用化への取組みが活発になっている．高臨場感 映像の研究動向としては, 観察者が没入感を得られる広視 野で高精細な映像技術や，あたかもそこに物体があるかの ような実在感が得られる立体映像がある。立体映像表示に は多くの方式があり，大別すれば 2 眼式や多眼式，体積表 示型，像再生型などに分類できる ${ }^{1)}$ 。これらの中でも，特 に像再生型立体表示は, 光により空間に像を再構成する方 式であるため, 実物を直接観察する時と同様に, 自然で見 やすい立体像が表示できる.

像再生型の一方式であるインテグラル立体映像方式 2)3)

2007 年 10 月 18 日, 立体映像技術研究会, 情報ディスプレイ研究会で発表 2008 年 1 月 7 日受付, 2008 年 8 月 13 日再受付, 2008 年 10 月 15 日採録 $\dagger \mathrm{NHK}$ 放送技術研究所 人間・情報

( ₹ 157-8510 東京都世田谷区砧 1-10-11, TEL 03-5494-3313) †日本ビクター株式会社 技術本部

（广 239-8550 神奈川県横須賀市神明町 58-7, TEL 046-836-7405)

$\dagger$ NHK Science \& Technical Research Laboratories

(1-10-11, Kinuta, Setagaya-ku, Tokyo 157-8510, Japan)

† Technology Development Division, Victor Company of Japan, Ltd. (58-7, Shinmei-cho, Yokosuka-shi, Kanagawa 239-8550, Japan)
は，撮影と表示時に微小なレンズの集合体（要素レンズア レー）を用いる．本方式は，特殊な眼鏡が不要であるとと もに，水平方向のみならず垂直方向の視差情報を有するな ど家庭用立体テレビに適した特徵を持つ。

これまで，著者らは，走査線 2000 本の映像技術を応用し たインテグラル立体テレビシステムを試作し，実時間の撮 影・表示機能など，テレビシステムとしての基本性能を実 証してきた ${ }^{4)}$. 今後，立体映像の表示性能の向上を図るに は, さらなる要素画像群の高精細化が必要である。 そこで, 現在ハイビジョンの 16 倍の画素数を持つ Super Hi-Vision （SHV）映像技術 5) 7) の立体表示への応用を進めている。 現在のところ SHV 映像表示は投射型ディスプレイにより実 現されている。 また，投射型ディスプレイを用いたインテ グラル立体映像表示では, 表示サイズを自由に変化させる ことができ，さらに，原理的にモアレが発生しないなどの 利点が多い．しかし，投射レンズは一般的に，投射画像の 中心からの距離である像高の高次関数で表される歪曲特性 を有するため, 表示された要素画像群は幾何学歪みを持つ. この要素画像の丕曲は, 要素画像と要素レンズとの位置ず れを引き起こすため, 再生立体像に空間的な歪曲や視域の 制限が生じ，画質が低下寸る。これまで，投射型のインテ 
グラル立体映像表示に関する研究はいくつかあるが 8) 10), 要素画像群を単一の高精細映像として投射表示した場合に ついて，その投射歪みが再生立体像に与える影響の解析や， 改善策に関する報告はなされていない.

そこで本論文は，投射型インテグラル立体映像方式に関 する一般的な性質として, 要素画像群の幾何学歪みとその 再生立体像の画質への影響の関係を明らかにすることを目 的とする。

まず, 1 次元のレンズアレーモデルを用いて, 要素画像 群の幾何学歪みと, 再生立体像の正規の位置からのずれに ついて解析する. 解析結果に対し, 幾何学歪みの一例とし て投射レンズの歪曲率が像高の 2 乗に比例する場合につい て, 其体的な数值を適用して再生像の歪曲の様子を調べる. 同時に, 直視型液晶モ二タを用いて, 数值計算と同じシス テムパラメータの表示実験系を組み, 要素画像群に計算に よって歪曲を与えて投射レンズの歪曲をシミュレートする. その状態で再生像の歪み测定を行い, 数值計算と比較検討 して解析結果の妥当性を検証する.

また，投射レンズの歪曲収差が視域角に与える影響を理 論的に解析する。同時に緑色画像の単板素子を用いた投射 型インテグラル立体映像表示系を組み，実際に視域角が制 限される様子を確かめる。

最後に, 要素画像群への歪み低減の画像処理が, 再生立 体像の歪曲の解消と制限されていた視域角の改善に効果的 であることを実証する。

\section{2. 投射型インテグラル立体映像方式}

投射型インテグラル立体映像方式の原理を図 1 に示す. 撮 像系では, レンズアレー中の各要素レンズによって, 各々に 対応する要素画像をカメラで取得する。このため, 各要素画 像は被写体を少しずつ違った角度から撮影したものになる. また，図 1 に示すように, 撮影用に屈折率分布 (Gradientindex; GRIN）レンズアレーを用いることで，再生像の逆 視現象を防ぎ，テレビシステムに要求される実時間の撮影・ 表示機能を実現できる ${ }^{11)}$.

表示系では, 撮影した要素画像群をスクリーンに投射表 示し，レンズアレーを通して観察する. 撮像系で撮影され た被写体からの光線が，この表示系により忠実に再現され， 空間に自然な立体像を再構成することができる。これらの システムでは, 奥行きも含めた 3 次元の空間情報を 2 次元 の画像として掫影・記録・伝送・表示できるため, テレビ システムに適した特徵を持っている．インテグラル立体映 像方式において, 再生立体像の一画素に相当するものはレ ンズアレーを構成する要素レンズ一個である。そのため要 素画像群に必要な総画素数は, 要素レンズ数と一要素画像 の画素数の積となり, 超高精細な要素画像群が必要となる. また, 再生立体像の解像度と, 立体像を観察できる範囲で ある視域の確保を両立するためにも, 膨大な画素数を持つ 画像が要求される.

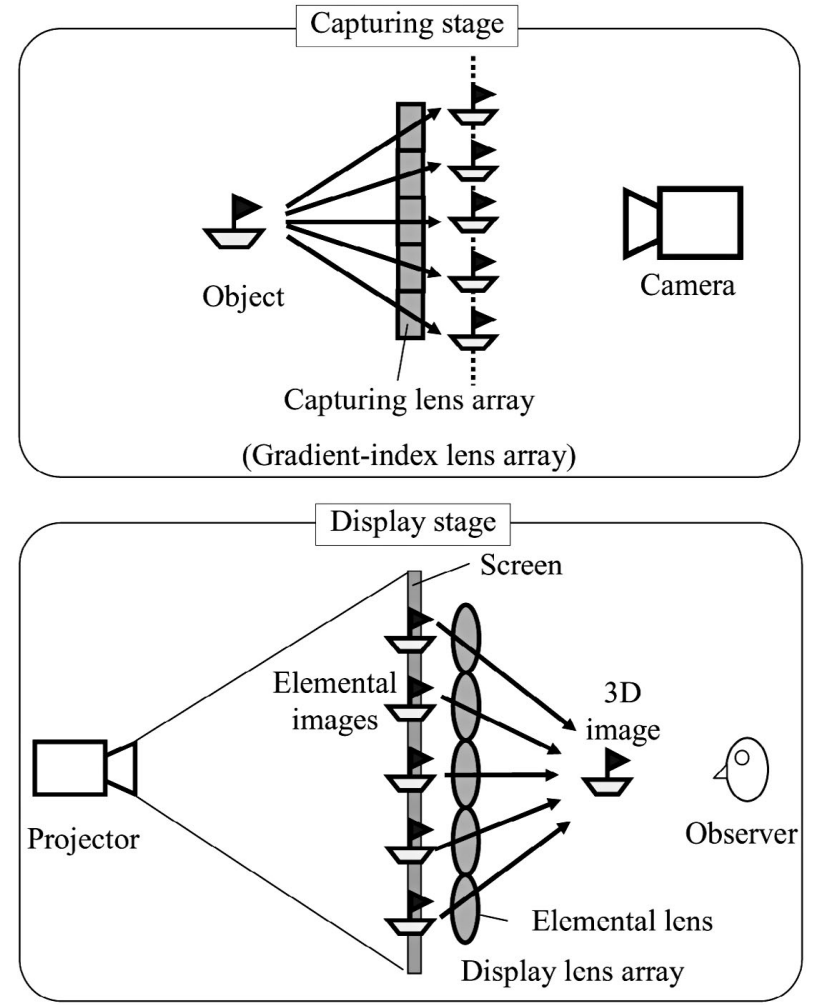

図 1 投射型インテグラル立体映像方式の原理

Principle of projection type integral 3D imaging system.

インテグラル立体映像方式では要素画像と要素レンズと の幾何学的な位置関係のずれによる画質低下が問題となる. これは直視型ディスプレイを要素画像群の表示に用いる場 合にも一部問題となるが ${ }^{12)}$ ，投射型のシステムでは，投射 レンズやハーフミラーなど, 投射光学系の歪曲収差に起因 する要素画像群の幾何学歪みが問題となる。なかでも, 投 射レンズの歪曲収差の影響が支配的である。

\section{3. 要素画像群の幾何学歪みが再生立体像に与える 影響}

図 2 に示すような 1 次元のレンズアレーモデルを用いて， 要素画像群の幾何学歪みと, それに起因する再生立体像の 歪曲の関係を解析する．実際のインテグラル立体映像方式 では, 2 次元のレンズアレーを用いるが, ここでは, 歪曲 の影響を端的に調べるため，1 次元レンズアレーモデルで 考える.なお， 2 次元レンズアレーの場合の考察について は, 第 6 章で詳述する.

要素画像群の幾何学歪みがない場合, 各要素画像からの 光線は対応する要素レンズを介して $A\left(x_{0}, z_{0}\right)$ 点に集光し, 再生像が形成されるものとする。 $i$ 番目の要素画像におけ る, $A$ 点の再生に寄与する点の位置 $x_{e, i}$ は,

$$
x_{e, i}=\frac{i P_{x}-x_{0}}{z_{0}} f
$$

となる．ただし $i$ 番目の要素レンズの光軸と要素画像の交 点を原点とする． $P_{x}$ はレンズピッチ， $i$ は像高 0 の位置の 要素レンズ（または要素画像）を 0 番目とした場合の要素 
レンズ (または要素画像) の番号である. $f$ はレンズアレー と要素画像間の距離であり, レンズアレーの焦点距離に等 しい.

この場合, $i$ 番目の要素レンズにより与えられる光線の $x$ 座標を $x_{i}(z)$ とすれば,

$$
x_{i}(z)=-\frac{x_{e, i}}{f} z+i P_{x}=\frac{x_{0}-i P_{x}}{z_{0}} z+i P_{x}
$$

と表すことができる。

一方, $x_{e, i}$ が幾何学歪みにより $\Delta x_{i}$ ずれた場合の位置 $x_{d, i}$ は,

$$
x_{d, i}=x_{e, i}+\Delta x_{i}=\frac{i P_{x}-x_{0}}{z_{0}} f+\Delta x_{i}
$$

となる.よって, 要素画像群に幾何学歪み $\Delta x_{i}$ が生じた場 合の光線の $x$ 座標 $x_{i}^{\prime}(z)$ は,

$x_{i}^{\prime}(z)=-\frac{x_{d, i}}{f} z+i P_{x}=\left(\frac{x_{0}-i P_{x}}{z_{0}}-\frac{\Delta x_{i}}{f}\right) z+i P_{x}$

\section{と記述できる。}

要素画像群に幾何学歪みが生じた状態では, 各要素レン ズによって与えられる光線は一点に収束せず, 図 2 に示す 様な広がりをもつ. なお, 各光線が最も集光する位置の代 表点を $B\left(x^{\prime}, z^{\prime}\right)$ 点とする.

像再生に寄与する要素レンズの個数 $N_{x}$ は, 再生像の位 置と荌素画像の領域で決まる（付録 $\mathrm{A}$ )。要素画像群に幾 何学歪みがない場合の再生点 $A$ において, 番号昇順に $b$ 番 目から $t$ 番目の要素レンズが再生に寄与するとすれば,

$$
N_{x}=t-b+1
$$

と表すことができる、また, 中心となる要素レンズを $m$ 番 目であるとすると，

$$
m=\frac{t+b}{2}
$$

である。

要素画像群に幾何学歪み $\Delta x_{i}$ がある場合に, この $m$ 番 目を中心とする要素レンズ群によって与えられる光線群の $x$ 座標の平均值 $\overline{x_{m}^{\prime}(z)}$ は, 式 (4) から以下のように求めら れる。

$$
\begin{aligned}
\overline{x_{m}^{\prime}(z)} & =\frac{1}{N_{x}} \sum_{i=b}^{t}\left[\left(\frac{x_{0}-i P_{x}}{z_{0}}-\frac{\Delta x_{i}}{f}\right) z+i P_{x}\right] \\
& =\left(\frac{x_{0}-m P_{x}}{z_{0}}-\frac{\overline{\Delta x_{m}}}{f}\right) z+m P_{x} \\
\overline{\Delta x_{m}} & =\frac{1}{N_{x}} \sum_{i=b}^{t} \Delta x_{i}
\end{aligned}
$$

各要素レンズによって作られる光線同士の幾何学的位置 の分散が, 最も小さくなる時, 各光線が最も集光している 点と見なせる. 各光線とそれらの平均值との距離の 2 乗和

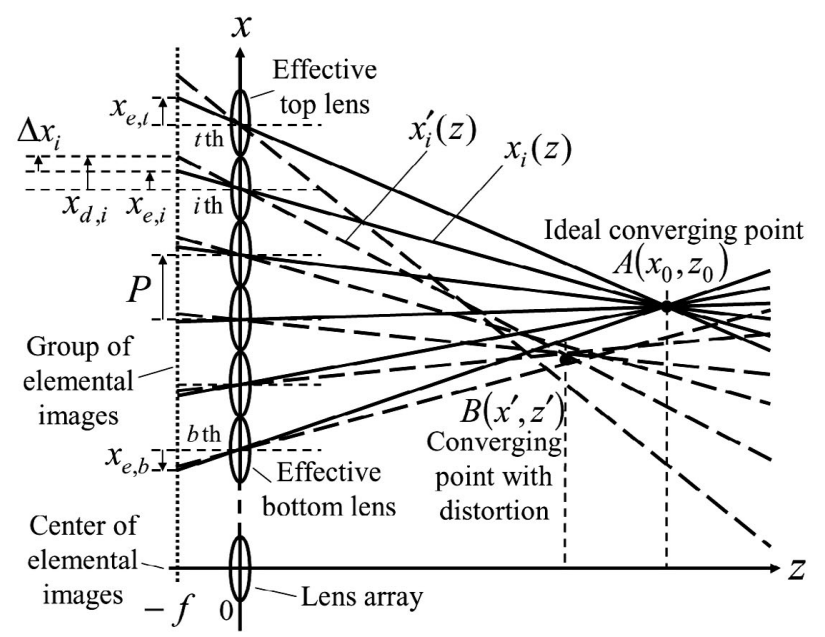

図 2 要素画像群の幾何学歪みによる再生像のずれ（1 次元レ ンズアレーモデル)

Geometrical error of reconstructed image causes the elemental images geometrical errors (One dimensional lens array model).

$\sigma_{x}^{2}(z)$ は,

$$
\sigma_{x}^{2}(z)=\frac{1}{N_{x}} \sum_{i=b}^{t}\left[x_{i}^{\prime}(z)-\overline{x_{m}^{\prime}(z)}\right]^{2}
$$

である。また，その導関数 $\frac{\mathrm{d}}{\mathrm{d} z} \sigma_{x}^{2}(z)$ は，

$$
\frac{\mathrm{d}}{\mathrm{d} z} \sigma_{x}^{2}(z)=\frac{2}{N_{x}} \sum_{i=b}^{t}\left[X_{i}^{2} z-(m-i) P_{x} X_{i}\right]
$$

となる。ただし，

$$
X_{i}=\frac{(m-i) P_{x}}{z_{0}}+\frac{\overline{\Delta x_{m}}-\Delta x_{i}}{f}
$$

とする. $\frac{\mathrm{d}}{\mathrm{d} z} \sigma_{x}^{2}(z)=0$ になる点が, 最も集光する位置の代 表点であるから, $N_{x} \geqq 2$ の時, $B\left(x^{\prime}, z^{\prime}\right)$ 点の座標は,

$$
\begin{aligned}
z^{\prime} & =\frac{\sum_{i=b}^{t}(m-i) P_{x} X_{i}}{\sum_{i=b}^{t} X_{i}^{2}} \\
x^{\prime} & =\left(\frac{x_{0}-m P_{x}}{z_{0}}-\frac{\overline{\Delta x_{m}}}{f}\right) z^{\prime}+m P_{x}
\end{aligned}
$$

と記述できる。なお， $N_{x}=1$ の時は，

$$
\begin{aligned}
& z^{\prime}=z_{0} \\
& x^{\prime}=x_{0}-\frac{\Delta x_{m}}{f} z_{0}
\end{aligned}
$$

とみなせる。

すなわち, $A\left(x_{0}, z_{0}\right)$ 点に再生されるべき光学像は, 要 素画像群の幾何学歪みの影響を受けると, 式 $(12)$ および 式 (13)，または式 (14) および式 (15) による座標変換を 受けて, $B\left(x^{\prime}, z^{\prime}\right)$ の位置にずれる。 


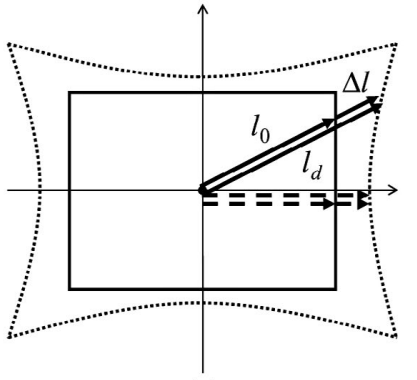

(a)

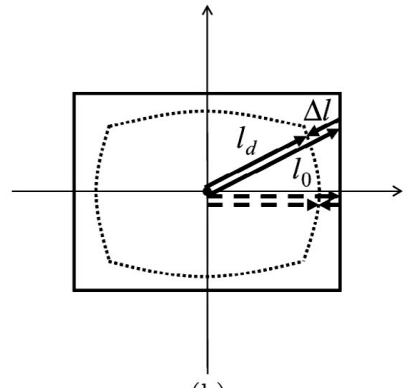

(b)
図 3 放射方向の歪曲収差 (歪曲率が像高の 2 乗に比例) (a):糸卷き型歪み (b):樽型歪み 実線:歪みなし 破線:歪みあり

Effect of radial distortion (Distortion is proportional to the square of the image height).

(a): Pincushion distortion, (b): Barrel distortion.

Solid lines: no distortion, Dashed lines: with distortion.

\section{4. 投射レンズによる要素画像群の幾何学歪み}

\section{1 投射レンズの歪曲収差}

本節では第 3 章で解析した要素画像群の幾何学歪みが, 特に投射レンズの歪曲収差に起因するものである場合につ いて考察する。

レンズには歪曲収差があり，大きく分けて，放射方向の 歪曲と, 接線方向の歪曲とに分類できる ${ }^{13) 14)}$. 一般的に, 接線方向の歪曲は放射方向の歪曲に比べて小さく, 投射画 像に与える影響も少ないため，ここでは放射方向の歪曲の みを考慮し，その歪曲率が，像高の 2 乗に比例する場合を 考える ${ }^{15)}$.

図 3 のように, 歪曲率 $D$ が像高の 2 乗に比例する場合, 任意の像高 $l_{0}$ における歪曲率 $D\left(l_{0}\right)$ は,

$$
D\left(l_{0}\right)=\frac{l_{d}-l_{0}}{l_{0}}=C l_{0}^{2}
$$

と表すことができる ${ }^{16)}$ ，ただし， $l_{0}$ は歪曲がない場合の像 高, $l_{d}$ は歪曲後の像高, $C$ は歪曲係数である. したがって, 画像の最大像高 $H$ に拈ける歪曲率 $D(H)$ は,

$$
\begin{aligned}
& D(H)=C H^{2} \\
& C=\frac{D\left(l_{0}\right)}{l_{0}^{2}}=\frac{D(H)}{H^{2}}
\end{aligned}
$$

である。これらから $l_{0}$ の点に扔ける歪み量 $\Delta l$ は $D(H)$ を 用いて次のように表すことができる。

$$
\Delta l=l_{d}-l_{0}=C l_{0}^{3}=\frac{D(H)}{H^{2}} l_{0}^{3}
$$

なお，本稿では，画像の中心（投射系の光軸）から像高が 最大となる要素レンズの位置を最大像高と定義する.

第 3 章の図 2 の要素画像群に関して, 放射方向の歪曲に ついて考える.この場合, 光線 $x_{i}^{\prime}$ に対応する要素画像画素 の像高は式 (4) から,

$\left.x_{i}^{\prime}(z)\right|_{z=-f}=x_{e, i}+i P_{x}+\Delta x_{i}=\frac{i P_{x}-x_{0}}{z_{0}} f+i P_{x}+\Delta x_{i}$
表 1 歪曲収差の計算パラメー夕

Calculation parameters of distorted aberration.

\begin{tabular}{l|l}
\hline \hline Pitch of elemental lens $\left(P_{x}\right)$ & $2.64[\mathrm{~mm}]$ \\
\hline Focal length of elemental lens $(f)$ & $8.58[\mathrm{~mm}]$ \\
\hline Number of elemental lenses & $141[\mathrm{pieces}](-70 \leqq i \leqq 70)$ \\
\hline Position of reconstructed image $\left(z_{0}\right)$ & $\pm 100[\mathrm{~mm}]$ \\
\hline Distortion in & $\pm 0.25, \pm 0.50, \pm 0.75$, \\
maximum image height $(D(H))$ & $\pm 1.00, \pm 1.25 \%$ \\
\hline \hline
\end{tabular}

である．また， $i_{\max }$ 番目の要素レンズの位置が最大像高に なり, 歪曲率を定義するための $l_{0}$ と $l_{d}$ は, 四 3 に扔いて破 線の矢印で示すような $x$ 軸上の像高になる。よって, 式 (19) の $\Delta l$ と $l_{0}$ の関倸を式 $(20)$ の $\Delta x_{i}$ と $x_{e, i}+i P_{x}$ にあては めると,

$$
\begin{aligned}
& \Delta x_{i}=\frac{D(H)}{H^{2}}\left(\frac{i P_{x}-x_{0}}{z_{0}} f+i P_{x}\right)^{3} \\
& H=i_{\max } P_{x}
\end{aligned}
$$

となる.

式 (21) および式 (22) に表 1 の各パラメー夕を与え, 式 (12) 掞よび式 (13) を用いて, 像高の 2 乗に比例した歪 曲収差が生じた場合の再生像の位置を計算した結果を図 4 に示す．横軸が再生像の奥行き方向位置，縦軸が再生像の 横方向位置を表している.

破線は, 再生像の位置が連続的な歪曲の変化に伴ってど のように変化するか, 歪みがない場合の再生像の 12 点の 像高 $x_{0}$ について調べたものである. 再生像の奥行き方向 位置は, 歪曲率が正値を示す系巻き型歪みの場合, 観測者 から見て奥の方向に歪む．逆に，歪曲率が貝值を示す樽型 歪みの場合, 観測者側手前方向に歪む. この傾向は再生像 の位置が表示レンズアレー面の手前であっても（図 4(a)）, 奥であっても（図 4(b)）同じである.一方, 再生像の横方 向位置は, 再生位置が表示レンズアレー面の手前にある場 合, 図 4(a) の破線からわかるように, 糸巻き型歪みでは画 面の内側方向に歪み，樽型歪みでは外側方向に歪む．また， 再生像の位置が奥にある場合は逆に，図 4(b) の破線のよ うに, 系巻き型歪みでは画面の外側方向に歪み, 樽型歪み では内側方向に歪む. 奥行き方向, 横方向共に, 再生位置 歪みは画面中心付近では小さく, 画面の中心からの距離に 従って大きくなる．像高の 2 乗に比例するレンズの歪曲収 差が再生位置歪みにも反映されていることがわかる.

次に, 最大像高に扔ける歪曲率 $D(H)$ を $0.50 \%$ に固定し, 歪みがない場合の再生像の奥行き位置 $z_{0}$ を，200[mm] か ら $-200[\mathrm{~mm}]$ の範囲で $50[\mathrm{~mm}]$ 毎に変化させた場合の計算 結果を図 5 に示す. 破線は, 再生像の横方向の位置と $z_{0}$ の 関係について, 図 4 の場合と同様に 12 点の像高 $x_{0}$ につい て調べたものである. 再生像の奥行き位置が表示レンズア レー面から離れているほど, 要素画像群の幾何学歪みの影 響を大きく受けている. $x_{0}=100.32[\mathrm{~mm}](m=38)$ の場 合の具体的数值を表 2 に示寸. 例えば, $z_{0}=100.0[\mathrm{~mm}]$ の位置に再生像を形成した時, 正規の再生奥行き距離の約 


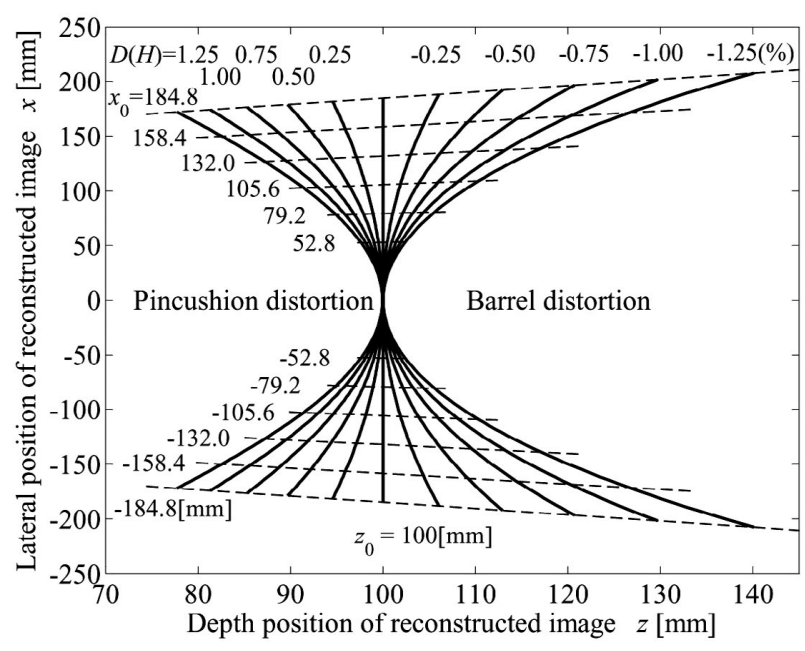

(a)

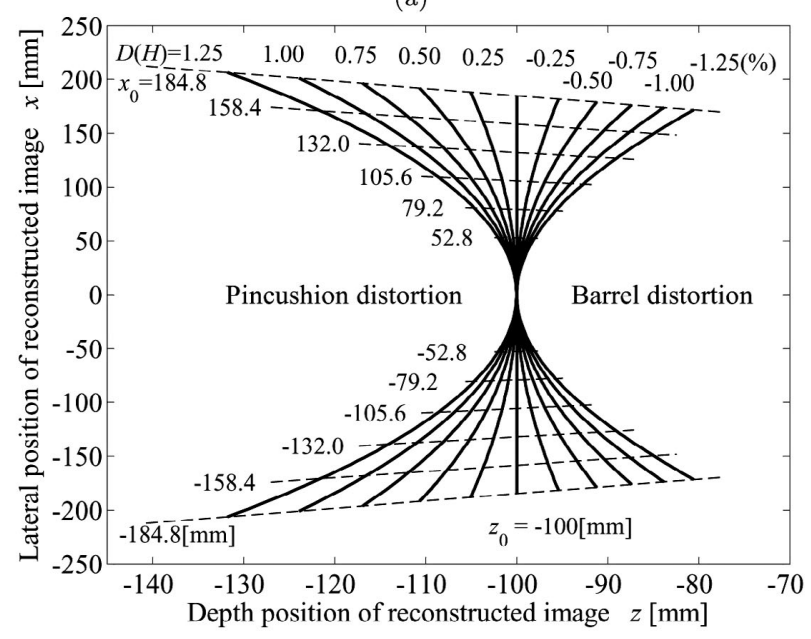

(b)

図 4 レンズの歪曲収差による再生像位置のずれ

(a): 再生像が表示面の手前にある場合 $\left(z_{0}=100[\mathrm{~mm}]\right)$,

(b):再生像が表示面の奥にある場合 $\left(z_{0}=-100[\mathrm{~mm}]\right)$

Geometrical error of reconstructed image based on lens distortion.

(a):When reconstructed image is in front of the lens array,

(b):When reconstructed image is behind the lens array.

表 2 再生像の奥行き方向の歪み [mm]

$\left(D(H)=0.50 \%, x_{0}=100.32[\mathrm{~mm}], \mathrm{m}=38\right)$

Depth directional distortion of reconstructed image [mm]

$\left(D(H)=0.50 \%, x_{0}=100.32[\mathrm{~mm}], \mathrm{m}=38\right)$.

\begin{tabular}{r|rrrrrrrr}
\hline \hline$z_{0}$ & -200.0 & -150.0 & -100.0 & -50.0 & 50.0 & 100.0 & 150.0 & 200.0 \\
\hline$z^{\prime}$ & -212.9 & -157.0 & -102.9 & -50.7 & 49.1 & 96.7 & 142.9 & 187.6 \\
\hline$\Delta z$ & -12.9 & -7.0 & -2.9 & -0.7 & -0.9 & -3.3 & -7.1 & -12.4 \\
\hline$\sigma_{x}$ & 0.165 & 0.064 & 0.016 & 0.001 & 0.002 & 0.022 & 0.074 & 0.173 \\
\hline \hline
\end{tabular}

3\%（3.3[mm]）に相当する量だけ再生像の位置が奥行き方 向に変化することがわかる. また, $\sigma_{x}\left(z^{\prime}\right)$ は式 $(9)$ の平方 根であり, 再生像の広がりの程度を表している。前述の条 件下では, 再生像の画素に相当する要素レンズの直径に比 較すると 10 分の 1 以下の值である.

再生像の奥行き位置 $z_{0}$ と, $x$ 軸方向のずれ量 $\Delta x=$ $x^{\prime}-x_{0}$ の関係を図 6 に示す．ただし， $D(H)=0.50 \%$ とした。このグラフは, 戝 5 に打いて破線の傾きとして表 されている再生像の横方向のずれ量と, $z_{0}$ の関係を示した ものである. 像高 $x_{0}=m P_{x}$ と再生像のレンズアレーから

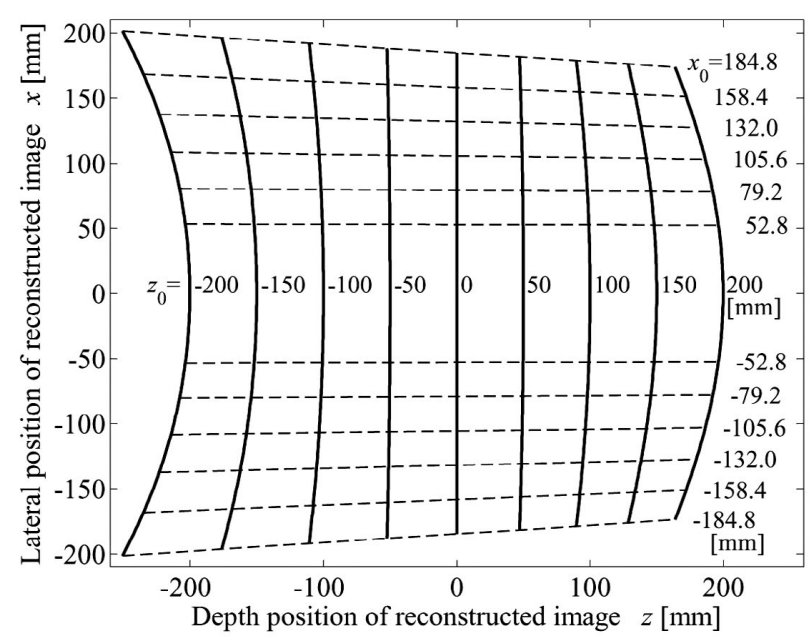

図 $\mathbf{5}$ 再生像の奥行き位置と歪曲の関係 $(D(H)=0.50 \%)$ Relation of reconstructed image position and image distortion $(D(H)=0.50 \%)$.

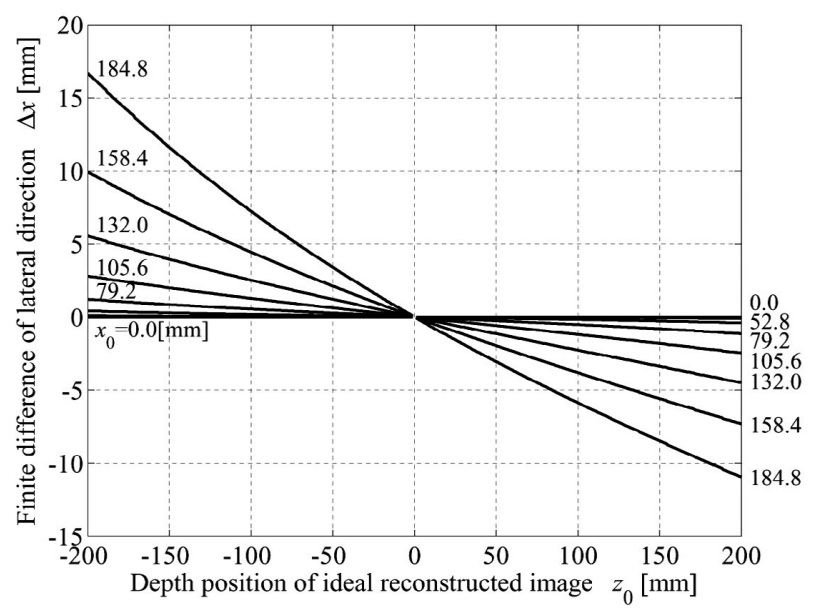

図 6 再生像の奥行き位置と横方向の歪曲の関倸 $(D(H)=$ $0.50 \%$ )

Relation of reconstructed image position and image distortion of lateral direction $(D(H)=0.50 \%)$.

の距離 $z_{0}$ に応じて, ずれ量の絶対值 $|\Delta x|$ が大きくなって いる.これは奥行き方向のずれ量の絶対值 $|\Delta z|$ に比べると 小さいが, 再生像の位置によっては要素レンズの直径に比 べて大きな值になるため，再生像に与える影響は無視でき ない.

\section{2 液晶モニタを用いたインテグラル立体表示装置に よる実測}

走査線 2000 本の直視型液晶モニ夕（有効表示領域の対 角約 21[inch]）を用いたインテグラル立体表示装置におい て，投射歪みをシミュレートして測定実験を行った，実験 系の仕様を表 3 に，構成と外観をそれぞれ図 7 および図 8 に示す.

実験では，理論検討で定義した像高の 2 乗に比例する歪 みを忠実に再現できるように，直視型モニ夕を用いた。こ のモニタには，理論解析で導出した計算式を基に生成した 歪みのある要素画像群を表示して，その再生位置を測定し， 理論検討と実験の比較ができるようにした. 
表 3 測定実験系の仕様

Specifications of experimental setup.

\begin{tabular}{l|l|l}
\hline \hline LCD panel & Effective number of pixels & $\approx 3200(\mathrm{H}) \times 2160(\mathrm{~V})$ \\
& Pixel width & $0.1245[\mathrm{~mm}]$ \\
\hline Lens array & Lens diameter & $2.64[\mathrm{~mm}]$ \\
& Number of lenses & $160(\mathrm{H}) \times 125(\mathrm{~V})$ \\
& Focal length & $8.58[\mathrm{~mm}]$ \\
\hline
\end{tabular}

Computer

(Generating distorted

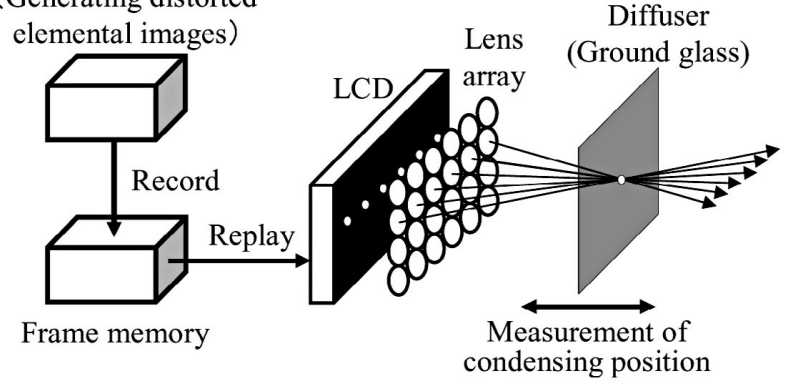

図 7 再生像位置の測定系

Measurement system of reconstructed image position.

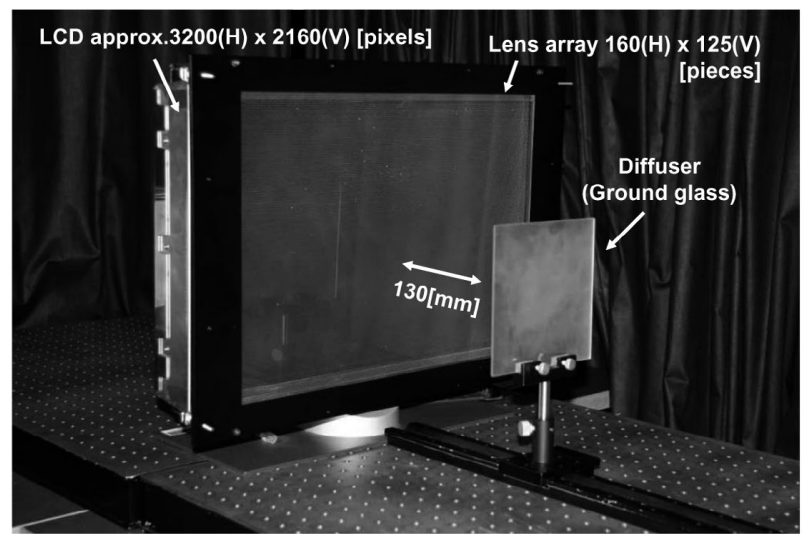

図 8 再生像位置の測定系

Measurement system of reconstructed image position.

再生像としては, レンズアレイ面から $130[\mathrm{~mm}]$ の位置 に浮かぶ点像を考光, それを再生する理想的な要素画像群 を計算して生成した。 その理想要素画像群の各点について, 式 (21) に基づき，レンズによる像高の 2 乗に比例する歪 曲収差を受けた時と同じ変換を要素画像群に与えた。

実験に用いた要素画像群の例の一部分を拡大したものを 図 9 に示す. 実際の要素画像群は，このような輝点群を画 面内に多数配置し, それぞれの画素に刘してその像高に応 じて前述の歪曲収差を与えたものである. 1 次元モデルの 理論検討について, 同等の条件でその妥当性を検証するた め, この実験では, 1 次元のレンズアレーによって再生さ れる光線を考えて要素画像群を作成した。 なお, 要素画像 では発光点を表現するため, 中心となる画素の光度を最大 とし, 近傍の隣接する 8 画素も使用して再生像の測定に必 要な光度を得られるようにした。 また, 要素画像の位置も 周辺画素で線形補間することでサブピクセルオーダの調整 を行った (図 9 拡大部)。このように, 要素画像の発光点は 理想的な点ではなく, 有限の大きさを持つため, レンズを 通して形成される光線は広がりを持つ. 理想的な発光位置

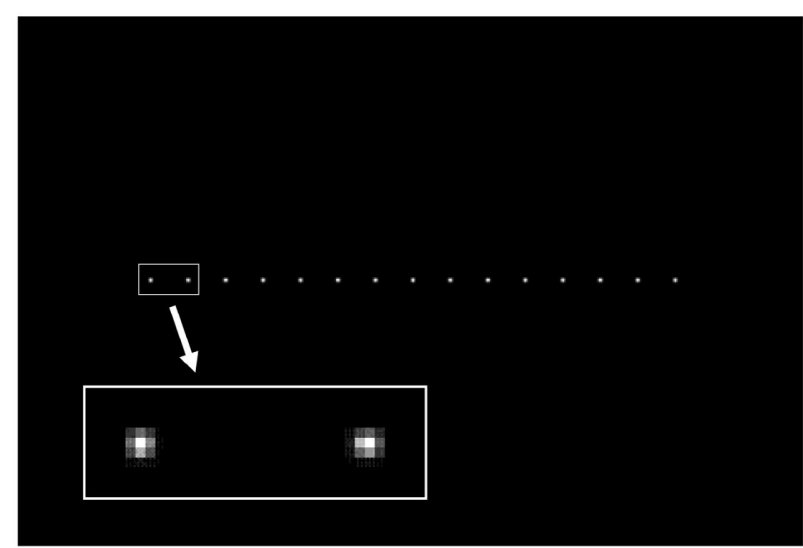

図 9 実験に用いた要䍗画像群の一例 (点像の再生に寄与するレンズの数: $N_{x}=15$, 要素画像の画素数:21.3[pixels])

Portion of the elemental image for experiment (number of lenses which contribute to reconstructed point image: $N_{x}=15$, number of pixels in an elemental image: $21.3[$ pixels] $)$.

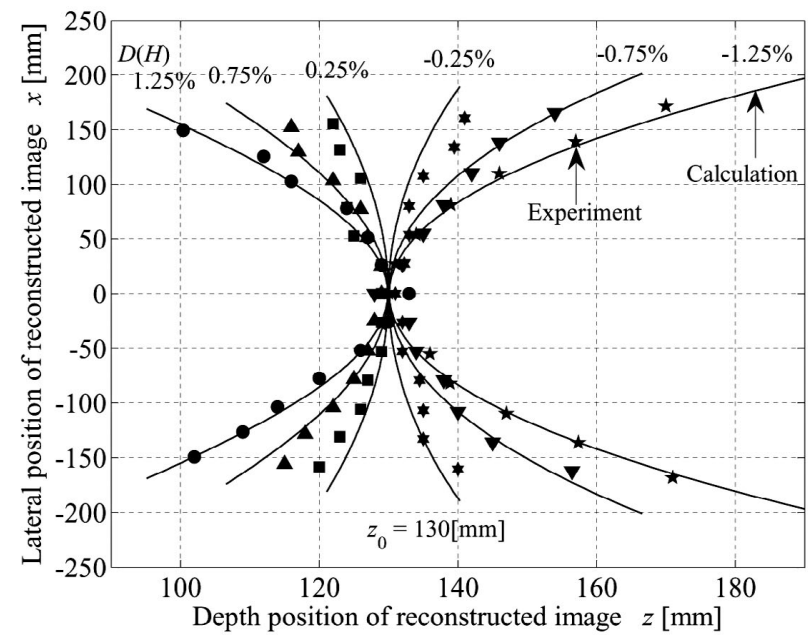

図 10 レンズの歪曲収差による再生像位置のずれ（実験と計算） Geometrical error of reconstructed image based on lens distortion (experimental and calculated result).

が画素の位置と一致しないために線形補間をした部分では， より多くの画素で発光点を表現することになるため, その 広がりはさらに大きくなる。

要素画像群に擬似的に加える歪みは, 最大像高における 歪曲率で $\pm 0.25, \pm 0.75, \pm 1.25 \%$ の 6 種類とし，それぞれ について測定を行った。 その他の仕様は，第 4.1 節におい て計算時に使用した表 1 に記載のものと同じである.

測定では図 7 および図 8 に示すように, 光線が拡散板（す りガラス）上で最も集光する位置を結像点とした。結像点 位置の同定は, $z$ 軸については拡散板とレンズアレー表面 相互の距離を計測することによって行った． $x$ 軸について は，拡散板上に結像点をプロットし，歪曲収差を与えてい ない画像を要素画像群として用いた場合の結像点（基準と なる結像点）との相互の距離を計測して求めた.

測定結果を第 4.1 節の理論值の計算結果に重ねて示した ものが図 10 である．歪曲率が大きくなるに従い， $z$ 軸方向 および $x$ 軸方向に再生位置がずれている，傾向は理論值と 


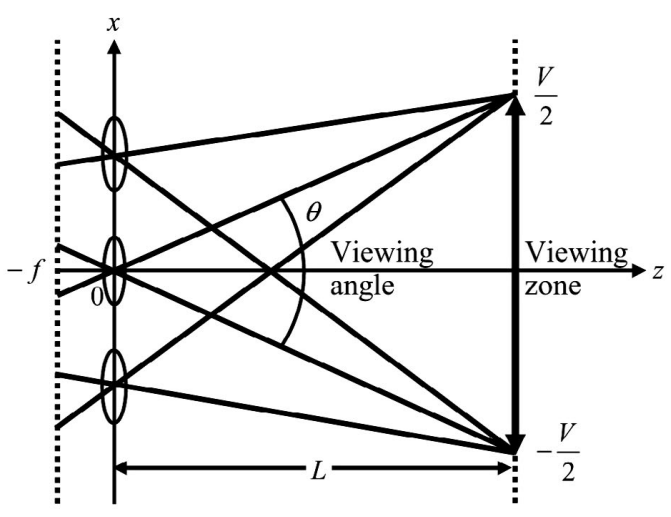

(a)

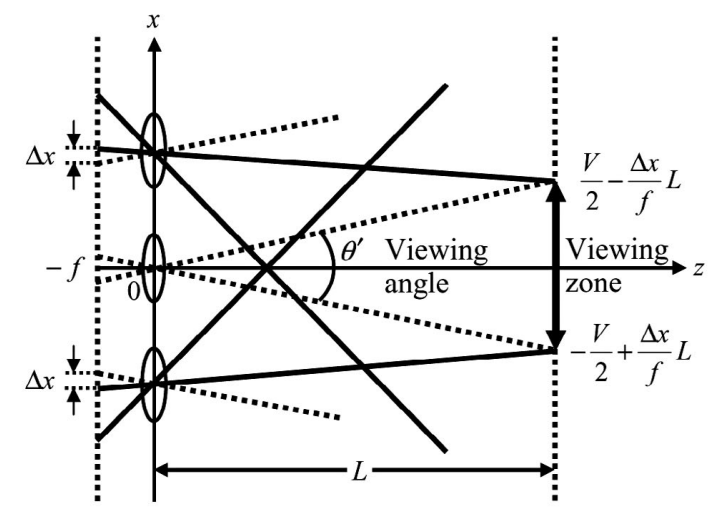

(b)

図 11 歪曲収差が再生立体像の視域角に与える影響 (a):歪みなしの場合 (b):歪みありの場合

Effect of distortion for reconstructed image viewing angle.

(a):Without distortion, (b):With distortion.

同じであり, 数值もほほ一致している.

測定時，拡散板上で点像の公がりが確認された。この㕕 がりには, 歪みの影響による収差の他に, 再生像がレンズ アレー面から遠くなるほど解像度が低下するインテグラル 方式の特性 ${ }^{18)}$ が寄与していると考えられる。ただし，理論 解析結果（表 2）で示したように, 歪みによる再生像の広 がりの程度 $\sigma_{x}\left(z^{\prime}\right)$ の值は小さい. そのため, レンズアレー 面から遠ざかることによるデフォーカスの影響が支配的で あり, 加えて, 画素が大きさを持つことや, 複数の画素で 要素画像の発光点が構成されていることが大きく影響して いると考えられる。

また，部分的に実験結果の值と理論值との間にずれがあ るのは, この点像の広がりに起因する測定誤差の影響であ ると推定できる.

\section{5. 投射レンズによる要素画像群の幾何学歪みが視 域角に与える影響}

投射レンズによる要素画像群の幾何学歪みが再生立体像 の視域角に与える影響について解析する（図 11）。視域角 とは，正しい再生立体像を観察することができる範囲（視 域）を見込む角度であり，要素画像群の幾何学歪みの影響 を受ける．図11(a)のように要素画像群に幾何学歪みがな

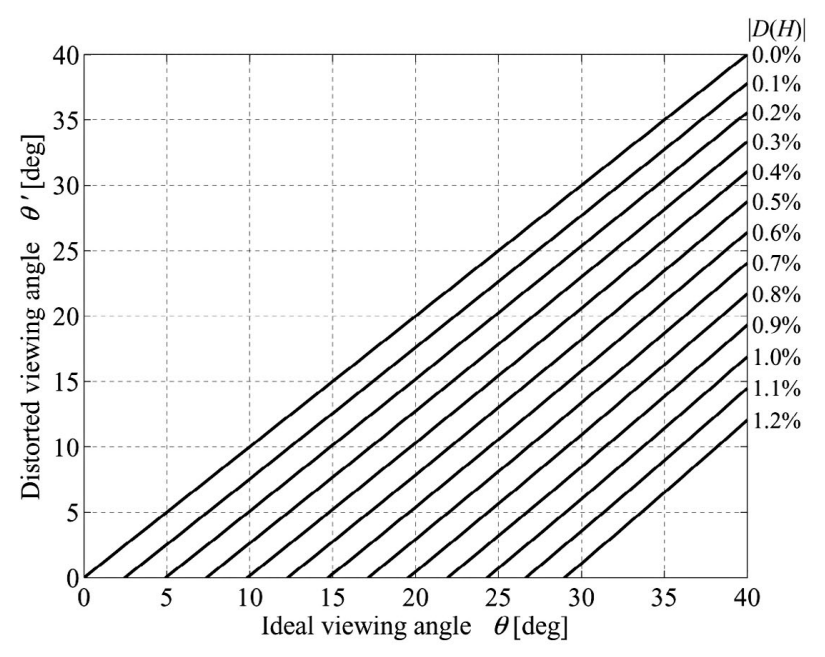

図 12 投射レンズの歪曲率と視域角の関係 (計算結果; $H=184.8[\mathrm{~mm}], f=8.58[\mathrm{~mm}]$ )

Relation between projection lens distortion and viewing angle (calculated result; $H=184.8[\mathrm{~mm}], f=8.58[\mathrm{~mm}]$ ).

い理想的な状態において，レンズアレーから距離 $L$ 離れた 場所での視域を $V$ とすると, 視域角 $\theta$ との関係は,

$$
\tan \frac{\theta}{2}=\frac{V}{2 L}
$$

である．要素画像群の最大像高に扔ける歪み量を $\Delta x$ とす ると（図 11(b)），影響を受けた視域角 $\theta^{\prime}$ は，

$$
\tan \frac{\theta^{\prime}}{2}=\frac{V}{2 L}-\frac{\Delta x}{f}
$$

となるので，これらから，

$$
\theta^{\prime}=2 \arctan \left(\tan \frac{\theta}{2}-\frac{|\Delta x|}{f}\right)
$$

の関係がなりたつ.式 $(25)$ より, 要素画像群の幾何学歪 みによって視域角が狭くなることがわかる，また，式 (19) 加,

$$
\theta^{\prime}=2 \arctan \left(\tan \frac{\theta}{2}-\frac{|D(H)| H}{f}\right)
$$

となる．図 12 は，投射レンズの歪曲率に応じて再生立 体像の視域角が狭くなる様子を式 (26) を基に, 最大像 高 $H=184.8[\mathrm{~mm}]$, レンズアレーと要素画像間の距離 $f=8.58[\mathrm{~mm}]$ として求めた結果である. 要素画像群の 幾何学歪みによる視域角の低減量は, 要素レンズの開口数 で決まる設計視域角に対して一定の比率で低減し，その低 減率は投射レンズの歪曲率にほぼ比例している.

表 1 のパラメータを持つシステムに执いて試算すると， 理想視域角は設計上 $17.5^{\circ}$ となるが，例えば，投射レンズ に起因する要素画像群の歪曲率が $0.05 \%$ の時, 実際の視域 角は $16.3^{\circ}$ になる。

次に，投射型のインテグラル立体映像表示実験系におい て, 歪曲収差が視域におよほすす影響と画像処理による改善 効果を調べる。第 4.2 節の実験では直視型モニ夕を用いた が，本実験では，投射型表示系を用いる，その理由は，投 
表 4 表示実験系の仕様

Specifications of experimental setup.

\begin{tabular}{l|l|l}
\hline \hline LCOS panel & Effective number of pixels & $\approx 3400(\mathrm{H}) \times 2300(\mathrm{~V})$ \\
& Pixel width & $6.8[\mu \mathrm{m}]$ \\
\hline Lens array & Lens diameter & $2.64[\mathrm{~mm}]$ \\
& Number of lenses & $160(\mathrm{H}) \times 125(\mathrm{~V})$ \\
& Focal length & $8.58[\mathrm{~mm}]$ \\
\hline Projection lens & Distortion & $1.1 \%$ \\
\hline \hline
\end{tabular}

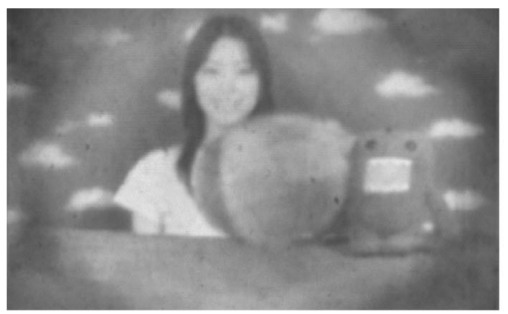

(a)

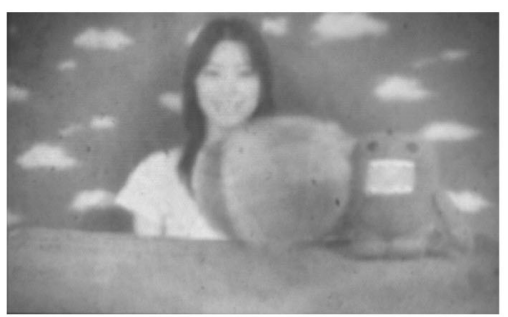

(b)

図 13 歪曲収差が再生立体像の視域へ与える影響の様子 (単板の LCOS パネルを使った表示実験結果) (a):歪み補正なしの場合 (b):歪み補正ありの場合 Effect of distortion for reconstructed image viewing zone (Experimental results of displaying using a LCOS panel).

(a):Without distortion compensation,

(b):With distortion compensation.

射レンズの歪曲収差に起因する視域の制限や再生像の奥行 き歪みが，歪み補正によって改善されることを実際に確か めるためである．使用した表示実験系の仕様を表 4 に示す. 対角 1.3[inch] の LCOS (Liquid crystal on silicon) パネ ル単板を使用し, 緑色の波長領域で要素画像群を再生表示 した。 それを背面投射スクリーン（有効表示領域の対角約 21[inch]）へ投射し，レンズアレーを介すことにより立体表 示を行った，投射レンズは，最大像高で $1.1 \%$ 歪曲率があ るものを使用した。

図 13(a) に要素画像群の幾何学歪みを補正しない場合の 再生立体像を示す．画面周辺に弧状の黒い部分が見られ, 視 野が狭くなっていることがわかるが，これは視域角の低減 に伴うものである. また, 視点を左右に移動させた場合, 再 生像の奥行き位置が見る位置により変化するため, 再生像 が歪んでいることがわかる。

そして, この要素画像群に, 投射レンズの $1.1 \%$ の歪みを 補正する画像処理を行い，立体表示した結果が図 13(b) で ある. 弧状の黒い部分が消え, 視野が広くなっていること から, 視域角の拡大が確認できる。この時, 実際に視域角 を測定してみると理想視域角と同じ $17.5^{\circ}$ であった。再生 像の奥行き方向の歪みも解消し，より撮影時の被写体に近 い状態に補正できることが確認できた。この画像処理に幾
何学補正装置 ${ }^{17)}$ を用いることで, 実時閒での撮影・表示も 可能となる.

\section{2 次元レンズアレーの場合の考察}

本論文では, 要素画像群の歪みが再生立体像に与える影 響の基本特性を調べるために, $x$ 軸方向のみの 1 次元のレ ンズアレーモデルを用いてきたが, $x, y$ 軸からなる 2 次元 レンズアレーの場合についても同様の方法で調べることが できる。

$y$ 軸方向の要素レンズの番号を $j$ 番目と表現すると, 要 素画像群に幾何学歪み $\Delta x_{i j}, \Delta y_{i j}$ が生じた場合の光線の $x$ 座標 $x_{i j}^{\prime}(z)$ および $y$ 座標 $y_{i j}^{\prime}(z)$ は式 (4)のように,

$$
\begin{aligned}
& x_{i j}^{\prime}(z)=\left(\frac{x_{0}-i P_{x}}{z_{0}}-\frac{\Delta x_{i j}}{f}\right) z+i P_{x} \\
& y_{i j}^{\prime}(z)=\left(\frac{y_{0}-j P_{x}}{z_{0}}-\frac{\Delta y_{i j}}{f}\right) z+j P_{x}
\end{aligned}
$$

と記述できる。

2 次元レンズアレーの場合, $y$ 軸では番号昇順に $d$ 番目 から $u$ 番目の要素レンズが再生に寄与するとすれば, 像再 生に寄与する $y$ 軸方向の要素レンズの個数 $N_{y}$ と, 中心と なる要素レンズの番号 $n$ は式 (5) および式 (6) と同様に,

$$
\begin{aligned}
& N_{y}=u-d+1 \\
& n=\frac{u+d}{2}
\end{aligned}
$$

である。また， $x$ 軸方向 $m$ 番目， $y$ 軸方向 $n$ 番目を中心と した場合を考えると, 像再生に寄与する要素画像群の幾何 学歪みの平均值 $\overline{\Delta x_{m n}}$ と $\overline{\Delta y_{m n}}$ （式 (8) に相当）は,

$$
\begin{aligned}
& \overline{\Delta x_{m n}}=\frac{1}{N_{x} N_{y}} \sum_{i=b}^{t} \sum_{j=d}^{u} \Delta x_{i j} \\
& \overline{\Delta y_{m n}}=\frac{1}{N_{x} N_{y}} \sum_{i=b}^{t} \sum_{j=d}^{u} \Delta y_{i j}
\end{aligned}
$$

となる. 各光線とそれらの均值との距離の 2 乗和 $\sigma_{x y}^{2}(z)$ は式 (9) と同様に,

$$
\begin{aligned}
\sigma_{x y}^{2}(z)= & \frac{1}{N_{x} N_{y}} \sum_{i=b}^{t} \sum_{j=d}^{u}\left\{\left[x_{i j}^{\prime}(z)-\overline{x_{m n}^{\prime}(z)}\right]^{2}\right. \\
& \left.+\left[y_{i j}^{\prime}(z)-\overline{y_{m n}^{\prime}(z)}\right]^{2}\right\}
\end{aligned}
$$

である.また，その導関数 $\frac{\mathrm{d}}{\mathrm{d} z} \sigma_{x y}^{2}(z)$ は,

$$
\begin{aligned}
\frac{\mathrm{d}}{\mathrm{d} z} \sigma_{x y}^{2}(z)= & \frac{2}{N_{x} N_{y}} \sum_{i=b}^{t} \sum_{j=d}^{u}\left[\left(X_{i j}^{2}+Y_{i j}^{2}\right) z\right. \\
& \left.-(m-i) P_{x} X_{i j}-(n-j) P_{y} Y_{i j}\right]
\end{aligned}
$$

となる。ただし，

$$
X_{i j}=\frac{(m-i) P_{x}}{z_{0}}+\frac{\overline{\Delta x_{m n}}-\Delta x_{i j}}{f}
$$




$$
Y_{i j}=\frac{(n-j) P_{y}}{z_{0}}+\frac{\overline{\Delta y_{m n}}-\Delta y_{i j}}{f}
$$

とし， $y$ 軸方向のレンズピッチを $P_{y}$ とする.したがって， 要素画像群に幾何学歪みがある場合の像の再生位置を表す, 各光線が最も集光する位置の代表点 $B\left(x^{\prime}, y^{\prime}, z^{\prime}\right)$ の座標は, $\frac{\mathrm{d}}{\mathrm{d} z} \sigma_{x y}^{2}(z)=0$ から次のように求められる.

$$
\begin{aligned}
& z^{\prime}=\frac{\sum_{i=b}^{t} \sum_{j=d}^{u}\left[(m-i) P_{x} X_{i j}+(n-j) P_{y} Y_{i j}\right]}{\sum_{i=b}^{t} \sum_{j=d}^{u}\left(X_{i j}^{2}+Y_{i j}^{2}\right)} \\
& x^{\prime}=\left(\frac{x_{0}-m P_{x}}{z_{0}}-\frac{\overline{\Delta x_{m n}}}{f}\right) z^{\prime}+m P_{x} \\
& y^{\prime}=\left(\frac{y_{0}-n P_{y}}{z_{0}}-\frac{\overline{\Delta y_{m n}}}{f}\right) z^{\prime}+n P_{y}
\end{aligned}
$$

$B\left(x^{\prime}, z^{\prime}\right)$ を表す式 (12) および式 (13) に比べると， $y$ 軸 方向の光線に関する $Y_{i j}$ の項が加わり, その寄与の分を総 和する形になっている。すすおち， 1 次元レンズアレーモ デルは $u=d=0$ の場合の特殊解であることがわかる.

ここで，投射レンズによる要素画像群の歪みは，画面中 心から放射方向への歪みが支配的であり, 歪曲率 $D$ は像高 の 2 乗に比例するものとする.この場合, 要素画像群の幾 何学歪み $\Delta x_{i j}$ と $\Delta y_{i j}$ は式 (21)の $\Delta x_{i}$ と同様に,

$$
\begin{aligned}
\Delta x_{i j}= & \frac{D(H)}{H^{2}}\left[\left(\frac{i P_{x}-x_{0}}{z_{0}} f+i P_{x}\right)^{3}\right. \\
& \left.+\left(\frac{i P_{x}-x_{0}}{z_{0}} f+i P_{x}\right)\left(\frac{j P_{y}-y_{0}}{z_{0}} f+j P_{y}\right)^{2}\right]
\end{aligned}
$$

$$
\begin{aligned}
\Delta y_{i j}= & \frac{D(H)}{H^{2}}\left[\left(\frac{j P_{y}-y_{0}}{z_{0}} f+j P_{y}\right)^{3}\right. \\
& \left.+\left(\frac{j P_{y}-y_{0}}{z_{0}} f+j P_{y}\right)\left(\frac{i P_{x}-x_{0}}{z_{0}} f+i P_{x}\right)^{2}\right]
\end{aligned}
$$

$$
H=\sqrt{i_{\max }^{2} P_{x}^{2}+j_{\max }^{2} P_{y}^{2}}
$$

となる．ただし， $j_{\max }$ 番目の要素レンズの位置を $y$ 軸方向 の最大像高とした． $x$ 軸方向と $y$ 軸方向はそれぞれ独立で はなく，相互に影響しあう関係にある。 $x$ 軸上だけを考え た $j=0$ の時, $\Delta x_{i j}$ は $\Delta x_{i}$ に等しい.

つまり, 2 次元レンズアレーの場合, $x$ 軸方向と $y$ 軸方 向の要素画像の歪み量が相互に影響しあい，それが再生像 にも反映される。このため, 再生像の位置は 1 次元レンズ アレーモデルの場合と同様に, 要素画像の糸巻き型や樽型 の歪みに応じて，画面中央方向や周辺方向，そして奥行き 方向へと歪む傾向にあるが，その絶対值は 1 次元モデルの 場合に比べて強調される。
また，式 (35) から式 (39) において，レンズピッチ $P_{x}$, $P_{y}$ は, $m P_{x} や(m-i) P_{x}$ のように原点や要素レンズ群 中心から各要素レンズまでの距離の值として影響している. このため， 2 次元レンズアレーにおいて， $x$ 軸方向と $y$ 軸 方向でレンズピッチが異なる $P_{x} \neq P_{y}$ の場合でも，その 影響は像再生に寄与するそれぞれの軸方向の光線の密度が 異なることだけである。すなわち，正方格子や俵積みなど， レンズの配置構造の違いに起因する歪曲特性の変化はない ことがわかる。

\section{7.むすび}

本論文では，投射型インテグラル立体表示システムにお ける要素画像の歪みが, 再生像に与元る影響を 1 次元レン ズアレーモデルによる解析と実験により明らかにした。投 射レンズによるわずかな歪曲収差が，再生立体像に大きな 歪みをもたらすことがわかった．特に周辺部に再生される 立体像の奥行き方向のずれが顕著であったままた，視域へ の影響も大きく，歪曲率にほほ比例して視域角が低減する ことが明らかになった．要素画像群の幾何学歪みを逆補正 する画像処理を施すことで，以上の歪みによる悪影響を低 減できることも実験により実証できた。

今回の結果より, SHVのように超高精細なプロジェクタ を用いた立体映像表示システムを設計・開発する際には，要 素画像群の歪みを極めて低く抑えることが必要であると推 測される，今後，要素画像と要素レンズの誤差を解消する ための低歪みの光学部品設計や高度な画像補正処理技術の 導入により，高画質なインテグラル立体映像表示の実現に 向けた取組みを行う。

な扮本研究は, 独立行政法人情報通信研究機構（NICT） の委託研究「多並列・像再生型立体テレビシステムの研究開 発」(2006 2010 年度) の一部として実施したものである.

\section{〔文献〕}

1）岡野文男：“立体映像技術の研究動向”, 映情学誌, 61, 5, pp.612-613 (May 2007)

2) M. G. Lippmann: "Épreuves réversibles donnant la sensation du relief", J. de Phys., $4^{\text {e }}$ série, VII, pp. 821-825 (Nov. 1908)

3) F. Okano, J. Arai, H. Hoshino and I. Yuyama: "Three-dimensional video system based on integral photography", Opt. Eng., 38, 6, pp. 1072-1077 (June 1999)

4) J.Arai, M.Okui, T.Yamashita and F.Okano: "Integral threedimensional television using a 2000-scanning-line video system", Appl. Opt., 45, 8, pp. 1704-1712 (Mar. 2006)

5) K. Hamada, M. Kanazawa, I. Kondoh, F. Okano, Y. Haino, M. Sato and K.Doi: "A Wide-Screen Projector of $4 \mathrm{k} \times 8 \mathrm{k}$ Pixels", SID Symposium Digest of Technical Papers, 33, 1, 46.3, pp. 1254-1257 (May 2002)

6) M.Sugawara, M. Kanazawa, K. Mitani, H. Shimamoto, T. Yamashita and F. Okano: "Ultrahigh-Definition Video System with 4000 Scanning Lines", Proc. SMPTE Motion Imaging, pp. 339346 (Oct./Nov. 2003)

7) M.Kanazawa, K.Hamada, I. Kondoh, F. Okano, Y.Haino, M. Sato and K. Doi: "An ultrahigh-definition display using the pixel-offset method", J. Int. SID, 12, 1, pp. 93-103 (Mar. 2004)

8) H. Liao, M. Iwahara, T.Koike, N. Hata, I. Sakuma and T. Dohi: "Scalable high-resolution integral videography autostereoscopic display with a seamless multiprojection system", Appl. Opt., 44, 3, pp. 305-315 (Jan. 2005) 
9) Y. Kim, J. Park, S. Min, S. Jung, H. Choi and B. Lee: "Wideviewing-angle integral three-dimensional imaging system by curving a screen and a lens array", Appl. Opt., 44, 4, pp. 546-552 (Feb. 2005)

10) M. Okui, J. Arai, Y. Nojiri and F. Okano: "Optical screen for direct projection of integral imaging", Appl. Opt., 45, 36, pp. 9132 9139 (Dec. 2006)

11) J. Arai, F. Okano, H. Hoshino and I. Yuyama: "Gradient-index lens-array method based on real-time integral photography for three-dimensional images", Appl. Opt., 37, 11, pp. 2034-2045 (Apr. 1998)

12) J. Arai, M. Okui, M. Kobayashi and F. Okano: "Geometrical effect of positional errors in integral photography", J. Opt. Soc. Am. A, 21, 6, pp. 951-958 (June 2004)

13) D. C. Brown: "Close-Range Camera Calibration", Photogrammetric Eng., 37, 8, pp. 855-866 (1971)

14) J. Weng, P. Cohen and M. Herniou: "Camera Calibration with Distortion Models and Accuracy Evaluation", IEEE Trans. Pattern Anal. \& Mach. Intell., 14, 10, pp. 965-980 (Oct. 1992)

15) J.C. McGlone, ed.: "Manual of Photogrammetry", Fifth edition, American Society for Photogrammetry and Remote Sensing, Bethesda, Maryland (2004)

16）関海克，白石賢二，渡辺一光，福岡宏樹，大橋和泰：“デジタルカメラ における画像補正技術”, Ricoh Technical Report, 31, pp. 103-110 (Dec. 2005)

17）日下部裕一，金澤勝，岡野文男：“超高精細映像表示システムのコンバー ゼンス䛊差と素子位置調整の自動化”, 映情学誌, 60, 2, pp. 234-241 (Feb. 2006)

18) J. Arai, H. Hoshino, M. Okui and F. Okano: "Effects of focusing on the resolution characteristics of integral photography", J. Opt. Soc. Am. A, 20, 6, pp. 996-1004 (June 2003)

19) K. E. Iverson: "A Programming Language", John Wiley \& Sons, Inc., New York, p. 12 (1962)

\section{〈付録〉}

\section{A． 像再生に寄与する要素レンズの範囲}

ここでは，像再生に寄与する要素レンズの範囲を考える. 図 2 のモデルに㧧いて，要素画像群に幾何学歪みがない場 合の再生点である $A$ 点の再生に, 番号昇順に $b$ 番目から $t$ 番目の要素レンズが寄与するものとする。なお，像高 0 の 位置に対応する要素レンズを 0 番日とする.

$t$ と $b$ の值を求めるにあたり，まず，任意の実数を整数化 する二つの関数を以下に示すように定義する ${ }^{19)}$.

$$
\begin{aligned}
& \lfloor r\rfloor=\text { floor }(r)=\max \{s \in \mathbb{Z} \mid s \leqq r\} \\
& \lceil r\rceil=\operatorname{ceiling}(r)=\min \{s \in \mathbb{Z} \mid r \leqq s\}
\end{aligned}
$$

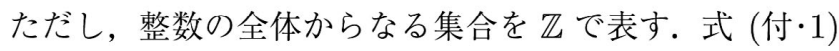
は，任意の実数 $r$ をそれを上回らない最大の整数に変換す る床関数である。一方，式 (付·2) は任意の実数 $r$ をそれを 下回らない最小の整数に変換する天井関数である.

各要素レンズが，ある位置における像再生に寄与してい るか否かは，図 2 に示すように，それぞれのレンズと対応 する要素画像の領域，そして像の再生位置の相互の幾何学 的関係によって決まる. 式 (1) から，

$$
\begin{aligned}
& \left\{\begin{array}{l}
\left|x_{e, t}\right|=\left|\frac{t P_{x}-x_{0}}{z_{0}} f\right|=\frac{t P_{x}-x_{0}}{\left|z_{0}\right|} f \leqq \frac{P_{x}}{2} \\
t \leqq i_{\max }
\end{array}\right. \\
& \left\{\begin{array}{l}
\left|x_{e, b}\right|=\left|\frac{b P_{x}-x_{0}}{z_{0}} f\right|=\frac{x_{0}-b P_{x}}{\left|z_{0}\right|} f \leqq \frac{P_{x}}{2} \\
b \geqq-i_{\max }
\end{array}\right.
\end{aligned}
$$

である．なお，最大像高の位置の要素画像に対応する要素レ ンズの番号を $i_{\max }$ とした。これらから， $t$ と $b$ はそれぞれ，

$$
\begin{aligned}
t & =\max \left\{i \in \mathbb{Z} \mid i \leqq \frac{x_{0}}{P_{x}}+\frac{\left|z_{0}\right|}{2 f}, i \leqq i_{\max }\right\} \\
& =\min \left(\left\lfloor\frac{x_{0}}{P_{x}}+\frac{\left|z_{0}\right|}{2 f}\right\rfloor, i_{\max }\right) \\
b & =\min \left\{i \in \mathbb{Z} \mid i \geqq \frac{x_{0}}{P_{x}}-\frac{\left|z_{0}\right|}{2 f}, i \geqq-i_{\max }\right\} \\
& =\max \left(\left[\frac{x_{0}}{P_{x}}-\frac{\left|z_{0}\right|}{2 f} \mid,-i_{\text {max }}\right)\right.
\end{aligned}
$$

と表すことができる.

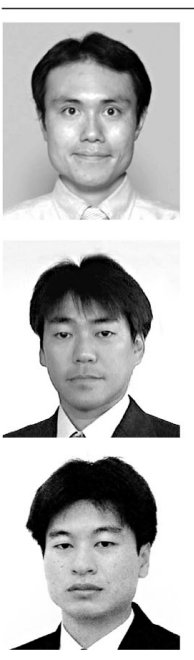

佐吉菜苍等 1999 年, 筑波大学第三学群工学システ 公学頑卒業. 2001 年, 同大学大学院工学研究科構造工学 専攻修士課程相当修了. 同年, NHK 入局. 秋田放送局 を経て，2006 年より放送技術研究所勤務. 立体映像の研 究に従事. 正会員.

河菲䔩䆖 1990 年，九州大学大学院修士課程修 了. 同年, NHK 入局. 鹿児島放送局を経て, 1992 年上 り放送技術研究所勤務. 液晶プロジェクタや 3 次元カメ ラの研究開発に従事. 2004 年より (財) NHK エンジニ アリングサービスへ出向. 2006 年より放送技術研究所勤 務，立体映像の研究に従事. 博士 (工学). 正会員.

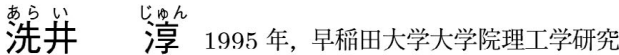
科修士課程修了. 同年, NHK 入局. 現在, 放送技術研 究所にて, 立体テレビ方式の研究に従事. 博士 (工学). 正会員.

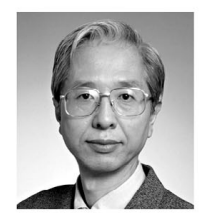

势風野 交文弯 1978 年, 東北大学大学院工学研究科 修士課程修了. 同年, NHK 入局. 名古屋放送局を経て, 1981 年から放送技術研究所勤務. ハイビジョンシステム の研究開発をカメラ中心に進める。 その後, 高臨場感映 像システムの研究に転じ，超高精細映像，インテグラル フォトグラフイやホログラフィなどの立体映像の研究に 従事. 博士 (工学) . 止会員.

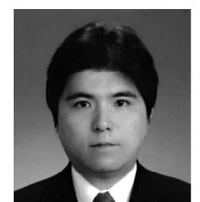

高黃呈也 1994 年, 九州大学大学院総合理工学 研究科修士課程修了. 1996 年, 日本学術振興会特別研究 員 (DC) . 1997 年, 総合研究大学院大学博士課程中退。 问年，日本ビクター（株）入社，技術本部にて計算機ホ ログラム応用システム開発，立体ディスプレイの研究開 発に従事.

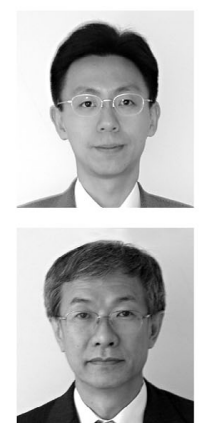

配里予 临行 1986 年, 東京電機大学工学部電子工 学科卒業、同年, 日本ビクター (株) 入社, 以来, ハイヒ ジョン, スーパーハイビジョン関連の研究開発扔よび商 品化開発に従事. 現在, 技術本部コア技術開発センター にて，超高精細映像システムおよび超臨場感システムの 研究開発に従事。正会員。

先志村䀓 1978 年, 早稲田大学工学部電気工学科 卒業. 同年, 百本ビクター (株) 入社. CRT ディスプレ イ, ハイビジョン TV 等の研究開発，商品化に従事. 現 在，技術本部コア技術開発センターにてスーパーハイビ ジョン等の超高精細 D-ILA プロジェクターの研究に従 事. 正会員.

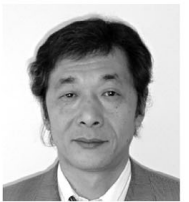

佐籐恝さと 1976 年, 明星大学工学部電気工学科 卒業. 1981 年, 目本ビクター（株）入社, 以来, コン ピュータ応用システム，画像厉縮 LSI, スーパーハイビ ジョンプロジェクター等の研究開発に従事. 現在, 同社技 術本部コア技術開発センター新映像システムユニット ユニットリーダー 